\title{
Glucagon-like peptide-1 receptor agonists and heart failure in type 2 diabetes: systematic review and meta-analysis of randomized and observational studies
}

Ling Li ${ }^{1}$, Sheyu Li ${ }^{2}$, Jiali Liu', Ke Deng ${ }^{3}$, Jason W. Busse ${ }^{4,5,6}$, Per Olav Vandvik ${ }^{7,8}$, Evelyn Wong ${ }^{9}$, Zahra N. Sohani ${ }^{4,10}$, Malgorzata M. Bala ${ }^{11,12}$, Lorena P. Rios ${ }^{13}$, German Malaga ${ }^{14}$, Shanil Ebrahim ${ }^{4,5,15,16}$, Jiantong Shen ${ }^{1}$, Longhao Zhang ${ }^{1}$, Pujing Zhao ${ }^{1}$, Qunfei Chen ${ }^{17}$, Yingqiang Wang ${ }^{18}$, Gordon H. Guyatt ${ }^{4,19}$ and Xin Sun ${ }^{*}$

\begin{abstract}
Background: The effect of glucagon-like peptide-1(GLP-1) receptor agonists on heart failure remains uncertain. We therefore conducted a systematic review to assess the possible impact of GLP-1 agonists on heart failure or hospitalization for heart failure in patients with type 2 diabetes.

Methods: We searched MEDLINE, EMBASE, the Cochrane Central Register of Controlled Trials (CENTRAL) and ClinicalTrials.gov to identify randomized controlled trials (RCTs) and observational studies that addressed the effect of GLP-1 receptor agonists in adults with type 2 diabetes, and explicitly reported heart failure or hospitalization for heart failure. Two paired reviewers screened reports, collected data, and assessed the risk of bias. We pooled data from RCTs and observational studies separately, and used the GRADE approach to rate the quality of evidence.
\end{abstract}

Results: We identified 25 studies that were eligible for our review; 21 RCTs ( $n=18,270)$ and 4 observational studies $(n=111,029)$. Low quality evidence from 20 RCTs suggested, if anything, a lower incidence of heart failure between GLP-1 agonists versus control (17/7,441 vs. 19/4,317; odds ratio (OR) 0.62, $95 \%$ confidence interval (Cl) 0.31 to 1.22; risk difference (RD) 19 fewer, $95 \%$ Cl 34 fewer to 11 more per 1000 over 5 years). Three cohort studies comparing GLP-1 agonists to alternative agents provided very low quality evidence that GLP-1 agonists do not increase the incidence of heart failure. One RCT provided moderate quality evidence that GLP-1 agonists were not associated with hospitalization for heart failure (lixisenatide vs placebo: 122/3,034 vs. 127/3,034; adjusted hazard ratio $0.96,95 \%$ Cl 0.75 to 1.23; RD 4 fewer, 95 \% Cl 25 fewer to 23 more per 1000 over 5 years) and a case-control study provided very low quality evidence also suggesting no association (GLP-1 agonists vs. other anti-hyperglycemic drugs: 1118 cases and 17,626 controls, adjusted OR 0.67, $95 \% \mathrm{Cl} 0.32$ to 1.42).

Conclusions: The current evidence suggests that GLP-1 agonists do not increase the risk of heart failure or hospitalization for heart failure among patients with type 2 diabetes.

Keywords: Glucagon-like peptide-1 receptor, Heart failure, Type 2 diabetes, Systematic review, Meta-analysis

\footnotetext{
* Correspondence: sunx79@hotmail.com

${ }^{1}$ Chinese Evidence-based Medicine Center, West China Hospital, Sichuan

University, 37 GuoXue Xiang, Chengdu 610041, Sichuan, China

Full list of author information is available at the end of the article
} 


\section{Background}

Glucagon-like peptide-1 (GLP-1) receptor agonists are a relatively new class of incretin-based agents for the treatment of type 2 diabetes mellitus that lower blood glucose $[1,2]$, reduce body weight [3], and possibly reduce cardiovascular risk compared to placebo $[4,5]$. The American Diabetes Association and the European Association for the Study of Diabetes recommend GLP-1 agonists as a second-line treatment option for type 2 diabetes [6].

In 2014, the US Food and Drug Administration raised concerns regarding heart failure risk with one dipeptidyl peptidase-4 (DPP-4) inhibitor, saxagliptin [7]. These concerns followed publication of studies that reported increased risk of hospitalization for heart failure in patients using DPP-4 inhibitors [8-10]. These observations raise the possibility that GLP-1 agonists, which share a similar pharmacological mechanism with DPP-4 inhibitors, might also cause heart failure.

Animal studies have shown that the GLP-1 agonist liraglutide can activate cytoprotective pathways in the heart, and improve outcomes after experimental myocardial infarction in mice [11]. Early clinical studies also suggested that GLP-1 agonists have positive effects on cardiovascular biomarkers, such as high-sensitivity Creactive protein and plasminogen activator inhibitor-1 $[12,13]$, and improve regional and overall left ventricular function in patients with acute myocardial infarction and severe systolic dysfunction after successful primary angioplasty [14].

Clinical trial results often, however, prove inconsistent with laboratory and surrogate outcome studies, and emerging randomized trials and observational studies have, reported inconsistent results [15-19]. We therefore undertook a systematic review to address the effect of GLP-1 agonists on heart failure or hospitalization for heart failure in patients with type 2 diabetes.

\section{Methods}

We followed the PRISMA and MOOSE guidelines for conducting and reporting systematic reviews and meta-analyses of randomized controlled trials (RCTs) and observational studies $[20,21]$.

\section{Data sources and search strategy}

We searched MEDLINE, EMBASE, and the Cochrane Central Register of Controlled Trials (CENTRAL) from inception to 25 June, 2015. We used both MeSH and free text terms to identify relevant articles. An information expert (DP) developed each database-specific search strategy (Additional file 1). We also searched ClinicalTrials.gov as well as conference abstracts published by the American Diabetes Association, European Association for the Study of Diabetes, and European Society of Cardiology for additional eligible studies and trial information.

\section{Eligibility criteria}

We included RCTs, cohort studies, or case-control studies that compared GLP-1 agonists against placebo, lifestyle modification, or active anti-hyperglycemic medication in adult type 2 diabetes patients, reported $\geq 12$ weeks follow-up data (not applicable to case-control studies), and explicitly reported the outcome of heart failure or hospitalization for heart failure.

\section{Study selection}

Paired reviewers, trained in research methods, independently screened titles/abstracts and then full texts for eligibility, assessed risk of bias, and collected data from each included study, using pilot-tested standardized forms with corresponding detailed instructions. Any disagreement between the two reviewers was resolved through discussion or adjudication by a third reviewer (XS).

\section{Risk of bias and quality of evidence assessment}

We assessed the risk of bias of RCTs according to modified version of the Cochrane Collaboration's tool $[22,23]$ in which the response options are "probably yes" and "probably no" instead of "unclear"; the approach has shown to be reliable and valid for blinding [24]. The items include randomization sequence generation; allocation concealment; blinding of participants, caregivers, outcome assessors (i.e., heart failure or hospitalization for heart failure), and outcome adjudicators; prognostic balance between treatment groups; and incomplete outcome data.

We used a modified version of the Newcastle - Ottawa Quality Assessment Scale [25-27] for assessing risk of bias of observational studies. Specifically, we removed two items "representativeness of the exposed cohort" and "was follow-up long enough for outcomes to occur" that we judge related to applicability, and added two items - ascertainment of type 2 diabetes and adjustment for potential confounding factors. We planned to assess for risk of publication bias, but were unable to do so due to low power of the relevant tests in the presence of low events rates.

We rated the quality of evidence for heart failure and hospitalization for heart failure as high, moderate, low, or very low using the Grading of Recommendations Assessment, Development and Evaluation (GRADE) methodology [28-34].

\section{Data extraction}

We collected the following information from each eligible studies: study characteristics (e.g., author name, year of publication, study design, sample size, length of follow-up), patient characteristics (e.g., gender, age, diabetes duration, body mass index (BMI), baseline HbA1c level), interventions (e.g., details of GLP-1 
agonists therapy and control group), and outcomes (number of events and patients included for analyses in each group, as well as adjusted data if available). For trials with multiple reports, we collated all data into a single study [35]; for trials with reports both from ClincialTrials.gov and journal publications, we carefully checked the data for consistency; for trials reporting outcome data of multiple follow up points, we used the data with longest follow up. For observational studies, we also collected information on data source, methods used to control confounding, and reported adjustment factors.

\section{Statistical analysis}

We analyzed RCTs and observational studies separately. We did not combine the outcomes of heart failure and hospitalization for heart failure, as hospitalization for heart failure is likely more serious and of greater importance to patients than heart failure not requiring hospitalization.

We assessed statistical heterogeneity with the Cochran chi-square test and I-squared statistic. We used Peto's method to pool data from RCTs [36, 37] using random effects models and reported pooled Peto odds ratios (ORs) and associated $95 \%$ confidence intervals (CIs). We conducted four a priori subgroup analyses to explore heterogeneity associated with our pooled estimates: (1) type of control (placebo vs. active treatment), (2) length of follow up (52 weeks or shorter vs. over 52 weeks), (3) mode of therapy (GLP-1 agonists monotherapy vs. addon/combination therapy), and (4) individual GLP-1 agonists agents (different GLP-1 agonists agents vs. control). We also carried out sensitivity analyses to explore the robustness of our findings using different effect measures, pooling methods, and statistical models.

We pooled adjusted estimates of heart failure from cohort studies using random effects model due to significant variations in the comparison and patient populations among eligible studies.

\section{Ethics}

Ethical approval was not necessary as this study is a Systematic Review and Meta-Analysis.

\section{Results}

\section{Study selection}

Our literature search yielded 11,441 reports; 821 were potentially eligible after title and abstract screening, and 25 studies proved eligible after full text screening. These included 21 RCTs involving 18,270 patients from 30 reports $[15,16,38-65]$ and four observational studies [17-19,66] involving 111,029 patients (three cohort studies and one nested case-control study) (Fig. 1).

\section{Evidence from randomized controlled trials} RCTs reporting heart failure

Twenty trials reported on heart failure; 18 (80\%) were multi-center studies, and 18 (90\%) were clearly labeled as phase III trials. These trials enrolled 46 to 1,091 patients (total 12,199); the mean age of patients ranged 52.9 to 67.2 years old, mean BMI 25.6 to $33.3 \mathrm{~kg} / \mathrm{m}^{2}$, mean baseline HbA1c 7.6 to $8.5 \%$, mean FPG 7.1 to $10.0 \mathrm{mmol} / \mathrm{L}$, and mean or median duration of diabetes was 2.6 to 11.5 years (Table 1). Five used GLP-1 agonists as monotherapy, 15 as add-on or combination therapy (Table 2). The length of follow-up ranged from 16 to 164 weeks (median 52; 10 trials followed patients for $>52$ weeks).

All the trials reported industry funding; 18 were identified from ClinicalTrials.gov, of which 12 had no corresponding journal publications. Because of the limited information provided in the trial registry, we were unable to adequately assess the risk of bias for these 12 trials. Additional file 2 presents the details of the assessment for risk of bias. The baseline demographics and clinical characteristics of patients in each included trials were generally balanced between groups. The overall risk bias of eligible RCTs was moderate.

Twenty trials reported 36 heart failure events in 11,758 patients using at least one medication (raw event rate $0.3 \%$ ). The pooling of those trials showed no statistically significant difference in the risk of heart failure between GLP-1 agonists treatment and control $(17 / 7,441$ in GLP-1 agonists and 19/4,317 control; OR $0.62,95 \%$ CI 0.31 to 1.22 , I-square $=0 \%$; risk difference (RD) 19 fewer, $95 \%$ CI 34 fewer to 11 more per 1000 over 5 years) (Fig. 2). We rated the quality of evidence as low because of risk of bias and imprecision (Table 3).

Subgroup analysis by type of control (interaction $p=$ 0.79 ), mode of therapy (interaction $p=0.84$ ) and length of follow up (interaction $p=0.64$ ) showed no differential treatment effects (Additional files 3, 4, 5 and 6). The subgroup analysis of heart failure risk by individual GLP-1 agonists agents suggested a possibility of differential treatment effect across individual agents (interaction $p=0.07$ ), with liraglutide associated with a non-significant increased risk for heart failure (OR 4.85, 95 \% CI 0.75 to $31.36)$; this finding was however based on a limited number of events (five in total) and characterized with very wide confidence interval.

Sensitivity analysis using alternative effect measures, statistical methods, and analysis models did not show important changes in pooled effects.

\section{Trials reporting hospitalization for heart failure}

The Evaluation of LIXisenatide in Acute Coronary Syndrome (ELIXA) trial, designed to assess the cardiovascular 


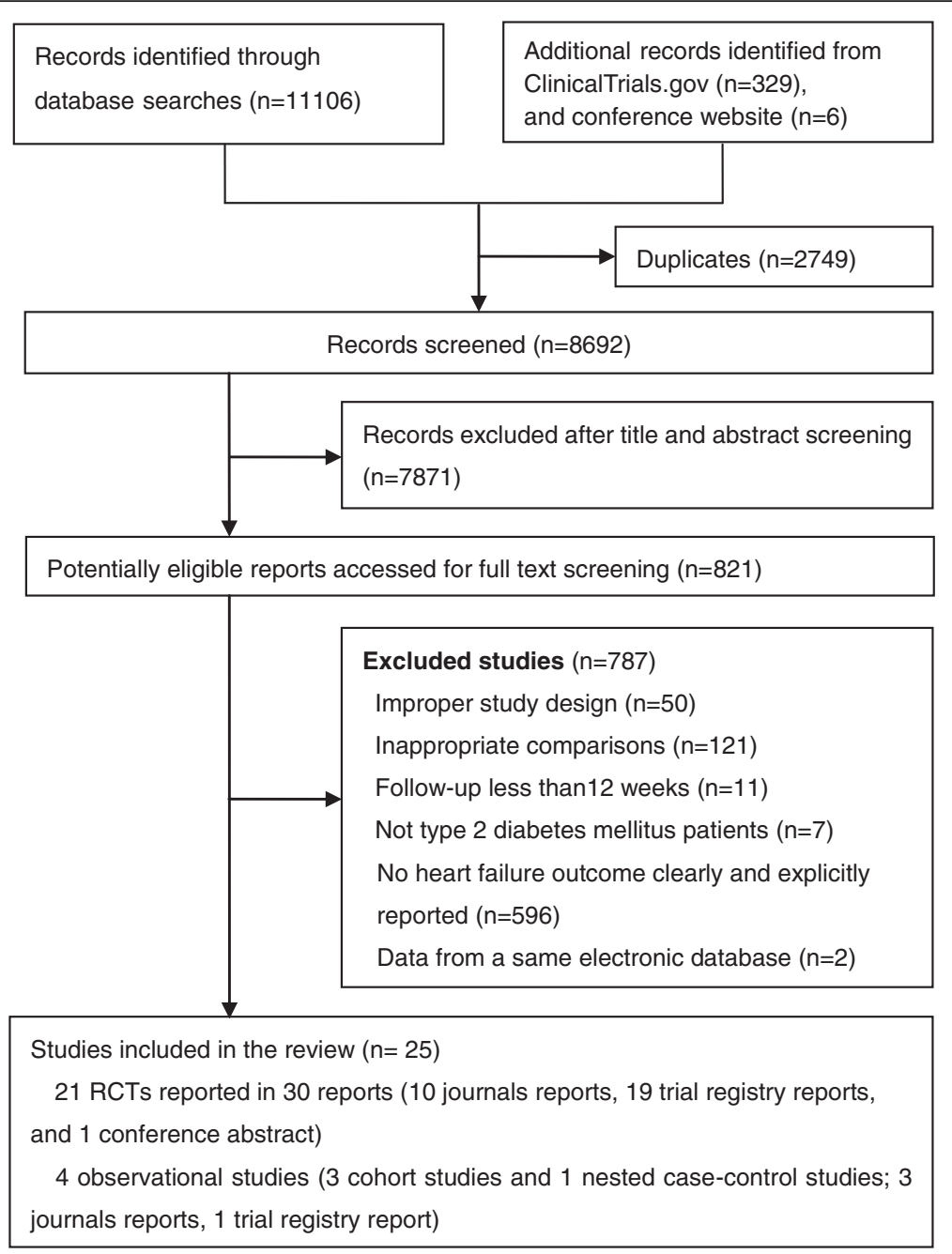

Fig. 1 Flow chart of article selection

safety of lixisenatide, reported hospitalization for heart failure $[15,16]$ (Table 1). The ELIXA trial randomized 6,068 patients with type 2 diabetes and a recent acute coronary syndrome to lixisenatide or placebo, with a median of follow up of 2.1 years. In this trial, 122 patients were hospitalized for heart failure among 3,034 patients taking lixisenatide (4.0\%) and 127 in 3034 patients taking placebo (4.2\%), and no statistically significant difference was present between the groups (hazard ratio (HR) 0.96, $95 \%$ CI 0.75 to 1.23; RD 4 fewer, $95 \%$ CI 25 fewer to 23 more per 1000 over 5 years). The trial authors' subgroup analysis by type of history of heart failure showed no differential treatment effects (lixisenatide vs. placebo: patients with history of heart failure: HR $0.93,95 \%$ CI 0.66 to 1.30 ; patients with no history of heart failure: HR 0.97, $95 \%$ CI 0.67 to 1.40 ). We rated the quality of evidence as moderate (Table 3 ).

\section{Evidence from observational studies Studies reporting heart failure}

Three cohort studies $[17,18,66]$ reported heart failure. Of these, one prospectively designed study [66] examined exenatide versus basal insulin; the other two $[17,18]$ - retrospective in design - assessed GLP-1 agonists versus sulfonylureas, and exenatide or exenatide plus insulin versus insulin (Tables 4 and 5 ). The sample sizes ranged from 882 to 39,225 , and length of follow up ranged from 1 to 4 years. The mean age ranged from 58.28 to 62.5 years, BMI 32.6 to $35.3 \mathrm{~kg} / \mathrm{m}^{2}$, and mean baseline HbA1c 7.9 to $8.9 \%$.

The three studies used electronic heath records or claims data for their analyses. Type 2 diabetes patients were ascertained by specialists in outpatient setting in the prospective cohort study [66]; the other two retrospective cohort study $[17,18]$ did not explicitly state the 
Table 1 Baseline characteristics of included randomized controlled trials

\begin{tabular}{|c|c|c|c|c|c|c|c|c|c|c|c|c|}
\hline Study & $\begin{array}{l}\text { International } \\
\text { study }\end{array}$ & $\begin{array}{l}\text { Number of } \\
\text { countries } \\
\text { involved }\end{array}$ & $\begin{array}{l}\text { Number } \\
\text { of study } \\
\text { sites }\end{array}$ & $\begin{array}{l}\text { Study } \\
\text { phase }\end{array}$ & $\begin{array}{l}\text { Total number } \\
\text { of patients } \\
\text { randomized }\end{array}$ & $\begin{array}{l}\text { Length of } \\
\text { follow up } \\
\text { (weeks) }\end{array}$ & $\begin{array}{l}\text { Male } \\
(n, \%)\end{array}$ & $\begin{array}{l}\text { Mean } \\
\text { age } \\
\text { (years) }\end{array}$ & $\begin{array}{l}\text { Mean BMl } \\
\left(\mathrm{kg} / \mathrm{m}^{2}\right)\end{array}$ & $\begin{array}{l}\text { Mean } \\
\text { HbA1c } \\
(\%)\end{array}$ & $\begin{array}{l}\text { Mean FPG } \\
(\mathrm{mmol} / \mathrm{L})\end{array}$ & $\begin{array}{l}\text { Mean } \\
\text { diabetes } \\
\text { duration } \\
\text { (years) }\end{array}$ \\
\hline \multicolumn{13}{|c|}{ Trials reporting heart failure } \\
\hline $\begin{array}{l}\text { Inagaki } 2012 \\
{[38,39]}\end{array}$ & No & 1 & $N R$ & III & 427 & 26 & $\begin{array}{l}290 \\
(67.9)\end{array}$ & 56.8 & 26.1 & 8.5 & NR & 9.0 \\
\hline $\begin{array}{l}\text { NCTO0294723 } \\
2010[40,41]\end{array}$ & Yes & 2 & 138 & III & 746 & 104 & $\begin{array}{l}371 \\
(49.7)\end{array}$ & 53.0 & 33.1 & 8.3 & 9.4 & 5.4 \\
\hline $\begin{array}{l}\text { NCT00318461 } \\
2010 \text { [42-44] }\end{array}$ & Yes & 21 & 170 & III & 1091 & 104 & $\begin{array}{l}635 \\
(58.2)\end{array}$ & 56.7 & 31.0 & 8.4 & 10.0 & 7.6 \\
\hline $\begin{array}{l}\text { NCT00360334 } \\
2009[45]\end{array}$ & No & 1 & 35 & III & 235 & 26 & $\begin{array}{l}160 \\
(68.4)\end{array}$ & 56.6 & NR & NR & NR & 6.0 \\
\hline $\begin{array}{l}\text { NCTO0614120 } \\
2010[46]\end{array}$ & Yes & 3 & 51 & III & 929 & 16 & $\begin{array}{l}514 \\
(55.3)\end{array}$ & 53.3 & 25.6 & NR & NR & 7.5 \\
\hline $\begin{array}{l}\text { NCTO0701935 } \\
2013[47]\end{array}$ & Yes & 2 & 17 & $\|$ & 80 & 26 & $\begin{array}{l}42 \\
(52.5)\end{array}$ & 58.1 & NR & NR & NR & NR \\
\hline $\begin{array}{l}\text { NCT00838903 } \\
2014[48,49]\end{array}$ & Yes & 10 & 289 & III & 1049 & 164 & $\begin{array}{l}482 \\
(47.6)\end{array}$ & 54.5 & 32.6 & 8.1 & 9.2 & 6.0 \\
\hline $\begin{array}{l}\text { NCT00838916 } \\
2014[50,51]\end{array}$ & Yes & 4 & 222 & III & 779 & 164 & $\begin{array}{l}418 \\
(56.1)\end{array}$ & 55.5 & 33.1 & 8.3 & 9.5 & 8.8 \\
\hline $\begin{array}{l}\text { NCT00839527 } \\
2014[52]\end{array}$ & Yes & 9 & 358 & III & 685 & 164 & $\begin{array}{l}353 \\
(53.2)\end{array}$ & 55.2 & NR & NR & $N R$ & NR \\
\hline $\begin{array}{l}\text { NCT00849017 } \\
2014 \text { [53] }\end{array}$ & Yes & 3 & 262 & III & 309 & 164 & $\begin{array}{l}166 \\
(55.1)\end{array}$ & 52.9 & NR & NR & NR & NR \\
\hline $\begin{array}{l}\text { NCT00849056 } \\
2014[54]\end{array}$ & Yes & 6 & 331 & III & 310 & 156 & $\begin{array}{l}180 \\
(59.8)\end{array}$ & 55.0 & NR & NR & NR & NR \\
\hline $\begin{array}{l}\text { NCT00855439 } \\
2015 \text { [55] }\end{array}$ & No & 1 & 1 & $N R$ & 46 & 82 & $\begin{array}{l}26 \\
(56.5)\end{array}$ & 53.0 & NR & NR & NR & NR \\
\hline $\begin{array}{l}\text { NCT00960661 } \\
2013[56,57]\end{array}$ & Yes & 17 & 108 & III & 637 & 30 & $\begin{array}{l}261 \\
(51.2)\end{array}$ & 59.5 & 32.5 & 8.2 & 7.1 & $11.5^{\mathrm{a}}$ \\
\hline $\begin{array}{l}\text { NCT01064687 } \\
2015[58]\end{array}$ & Yes & 3 & 89 & III & 978 & 26 & $\begin{array}{l}570 \\
(58.4)\end{array}$ & 55.7 & 33.2 & 8.1 & 9.0 & 8.8 \\
\hline $\begin{array}{l}\text { NCT01075282 } \\
2015 \text { [59] }\end{array}$ & Yes & 20 & 78 & III & 810 & 78 & $\begin{array}{l}353 \\
(51.3)\end{array}$ & 56.7 & 31.6 & 8.1 & 9.1 & 9.1 \\
\hline $\begin{array}{l}\text { NCT01126580 } \\
2015[60,61]\end{array}$ & Yes & 19 & 91 & III & 807 & 56 & $\begin{array}{l}353 \\
(43.7)\end{array}$ & 55.6 & 33.3 & 7.6 & 9.0 & 2.6 \\
\hline $\begin{array}{l}\text { NCT01191268 } \\
2014[62]\end{array}$ & Yes & 16 & 101 & III & 884 & 52 & $\begin{array}{l}473 \\
(53.5)\end{array}$ & 59.4 & 32.5 & 8.5 & $N R$ & 12.7 \\
\hline $\begin{array}{l}\text { NCT01512108 } \\
2014 \text { [63] }\end{array}$ & No & 1 & 36 & III & 363 & 52 & $\begin{array}{l}262 \\
(72.8)\end{array}$ & 59.5 & NR & 8.1 & 8.8 & NR \\
\hline $\begin{array}{l}\text { NCT01620489 } \\
2014 \text { [64] }\end{array}$ & Yes & 6 & 50 & III & 277 & 26 & $\begin{array}{l}140 \\
(50.5)\end{array}$ & 67.2 & $N R$ & NR & $N R$ & NR \\
\hline $\begin{array}{l}\text { Pratley } \\
2013 \text { [65] }\end{array}$ & Yes & 17 & 130 & III & 760 & 24 & $\begin{array}{l}362 \\
(48.9)\end{array}$ & 56.4 & 32.7 & 8.3 & 10.0 & 8.8 \\
\hline \multicolumn{13}{|c|}{ Trials reporting hospitalization for heart failure } \\
\hline $\begin{array}{l}\text { Bentley-Lewis } \\
2015 \text { (ELIXA) } \\
{[15,16]}\end{array}$ & Yes & 49 & NR & III & 6068 & $108^{\mathrm{b}}$ & $\begin{array}{l}4207 \\
(69.3)\end{array}$ & 60.3 & 30.2 & 7.7 & 8.2 & 9.3 \\
\hline
\end{tabular}

$B M I$ body mass index, FPG fasting plasma glucose, NR not reported

${ }^{a}$ median diabetes duration (years); ${ }^{b}$ median follow up time (weeks)

ascertainment of type 2 diabetes. None of these studies mentioned the ascertainment of exposure to GLP-1 agonist agents and other confounding variables. Only one study [17] demonstrated that outcome of interest was not present at start of study, and mentioned the method used to assess the outcome of interest. Two 
Table $\mathbf{2}$ Intervention tested and event rates in randomized controlled trials

\begin{tabular}{|c|c|c|c|c|c|c|}
\hline \multirow[t]{2}{*}{ Study } & \multirow[t]{2}{*}{ Medications used across groups } & \multicolumn{2}{|l|}{ Incretin } & \multicolumn{2}{|l|}{ Control } & \multirow{2}{*}{$\begin{array}{l}\text { Duration of } \\
\text { treatment } \\
\text { (weeks) }\end{array}$} \\
\hline & & Type & Events & Type & Events & \\
\hline \multicolumn{7}{|l|}{ Trials reporting heart failure } \\
\hline Inagaki 2012 [38, 39] & $\mathrm{BG}$ or $\mathrm{BG}+\mathrm{TZD}$ & Exenatide & $1 / 215$ & Insulin glargine & $0 / 212$ & 26 \\
\hline NCT00294723 $2010[40,41]$ & None & Liraglutide & $1 / 497$ & Glimepiride & $0 / 248$ & 104 \\
\hline \multirow[t]{2}{*}{ NCT00318461 2010 [42-44] } & Metformin & Liraglutide & $1 / 724$ & Placebo & $0 / 121$ & 104 \\
\hline & & Liraglutide & $1 / 724$ & Glimepiride & $0 / 242$ & \\
\hline NCT00360334 2009 [45] & OADs & Exenatide & 0/118 & Insulin glargine & $1 / 116$ & 26 \\
\hline NCT00614120 2010 [46] & Merformin & Liraglutide & $1 / 697$ & Glimepiride & $0 / 231$ & 16 \\
\hline NCT00701935 2013 [47] & None & Exenatide & $0 / 43$ & Placebo & $1 / 37$ & 26 \\
\hline \multirow[t]{2}{*}{ NCT00838903 $2014[48,49]$} & Metformin & Albiglutide & $2 / 302$ & Placebo & 0/101 & 156 \\
\hline & & Albiglutide & $2 / 302$ & Glimepiride & $1 / 307$ & \\
\hline NCT00838916 $2014[50,51]$ & Metformin $\pm S U$ & Albiglutide & $2 / 504$ & Insulin glargine & $2 / 241$ & 156 \\
\hline \multirow[t]{2}{*}{ NCT00839527 2014 [52] } & Metformin + glimepiride & Albiglutide & $0 / 271$ & Placebo & $1 / 115$ & 164 \\
\hline & & Albiglutide & $0 / 271$ & Pioglitazone & $4 / 277$ & \\
\hline NCT00849017 2014 [53] & None & Albiglutide & $1 / 200$ & Placebo & $2 / 101$ & 164 \\
\hline NCT00849056 2014 [54] & Pioglitazone \pm Metformin & Albiglutide & $0 / 150$ & Placebo & $1 / 151$ & 156 \\
\hline NCT00855439 2015 [55] & Other diabetes medications & Exenatide & $1 / 22$ & Glargine & $1 / 24$ & 78 \\
\hline NCT00960661 $2013[56,57]$ & Insulin glargine + metformin & Exenatide & $0 / 315$ & Insulin lispro & $1 / 312$ & 30 \\
\hline \multirow[t]{2}{*}{ NCT01064687 2015 [58] } & Metformin and pioglitazone & Dulaglutide & $1 / 559$ & Placebo & $0 / 141$ & 26 \\
\hline & & Exenatide & $0 / 278$ & Placebo & $0 / 141$ & \\
\hline NCT01075282 2015 [59] & Metformin and glimepiride & Dulaglutide & $3 / 545$ & Insulin glargine & $1 / 262$ & 78 \\
\hline NCT01126580 $2015[60,61]$ & None & Dulaglutide & $1 / 539$ & Metformin & $0 / 268$ & 52 \\
\hline NCT01191268 2014 [62] & Insulin lispro & Dulaglutide & $0 / 588$ & Insulin glargine & $1 / 296$ & 52 \\
\hline NCT01512108 2014 [63] & None & Liraglutide & $1 / 240$ & Additional OAD & $0 / 120$ & 52 \\
\hline NCT01620489 2014 [64] & OAD and/or insulin & Liraglutide & $1 / 140$ & Placebo & 0/137 & 26 \\
\hline Pratley 2013 [65] & $\mathrm{SU} \pm$ metformin & Taspoglutide & $0 / 494$ & Pioglitazone & $2 / 257$ & 24 \\
\hline \multicolumn{7}{|c|}{ Trials reporting hospitalization for heart failure } \\
\hline Bentley-Lewis 2015 (ELIXA) [15, 16] & $\begin{array}{l}\text { Metformin, SU, glinide, TZD, insulin, } \\
\text { metformin and SU, insulin and OADs, } \\
\text { or other diabetes medications }\end{array}$ & Lixisenatide & $122 / 3034$ & Placebo & $127 / 3034$ & 100 \\
\hline
\end{tabular}

$B G$ biguanide, $T Z D$ thiazolidinedione, $O A D$ s oral antidiabetic drugs, $S U$ sulfonylurea

studies $[18,19]$ used advanced statistical model to control for the influence of confounding factors. Overall, the risk of bias associated with these studies was moderate to high (Additional file 7).

All three studies reported raw data, for a total of 2,868 heart failures among 53,292 patients (raw event rate $5.4 \%$ ); two retrospective cohort studies $[17,18]$ reported adjusted effect estimates (Tables 5 and 6). The prospective cohort study [66], enrolling 882 patients with one year follow-up, found that two patients $(2 / 438)$ in the basal insulin had heart failure events and no patients $(0 / 444)$ in exenatide group. One retrospective cohort study [17], including 13,185 patients and with a median follow-up of four years, reported that GLP-1 agonists were associated with a nonsignificant increase in heart failure versus sulfonylureas (adjusted HR 1.10, 95 \% CI 0.99 to 1.22). The other retrospective cohort study [18], involving 39,225 patients and with a median follow-up of 3.5 years, found that both exenatide and exenatide plus insulin were associated with a lower risk of heart failure versus insulin alone (adjusted HR 0.34, 95 \% CI 0.22 to 0.52; adjusted HR 0.40, 95 \% CI 0.32 to 0.50 , respectively, Fig. 3). Using GRADE, we rated the quality of evidence in the included studies as very low, due to risk of bias, indirectness and heterogeneity in addition to the inherent risk for confounding associated with observational studies.

\section{Studies reporting hospitalization for heart failure}

One nested case-control study [19] assessed with GLP-1 agonists versus other oral anti-hyperglycemic drugs 


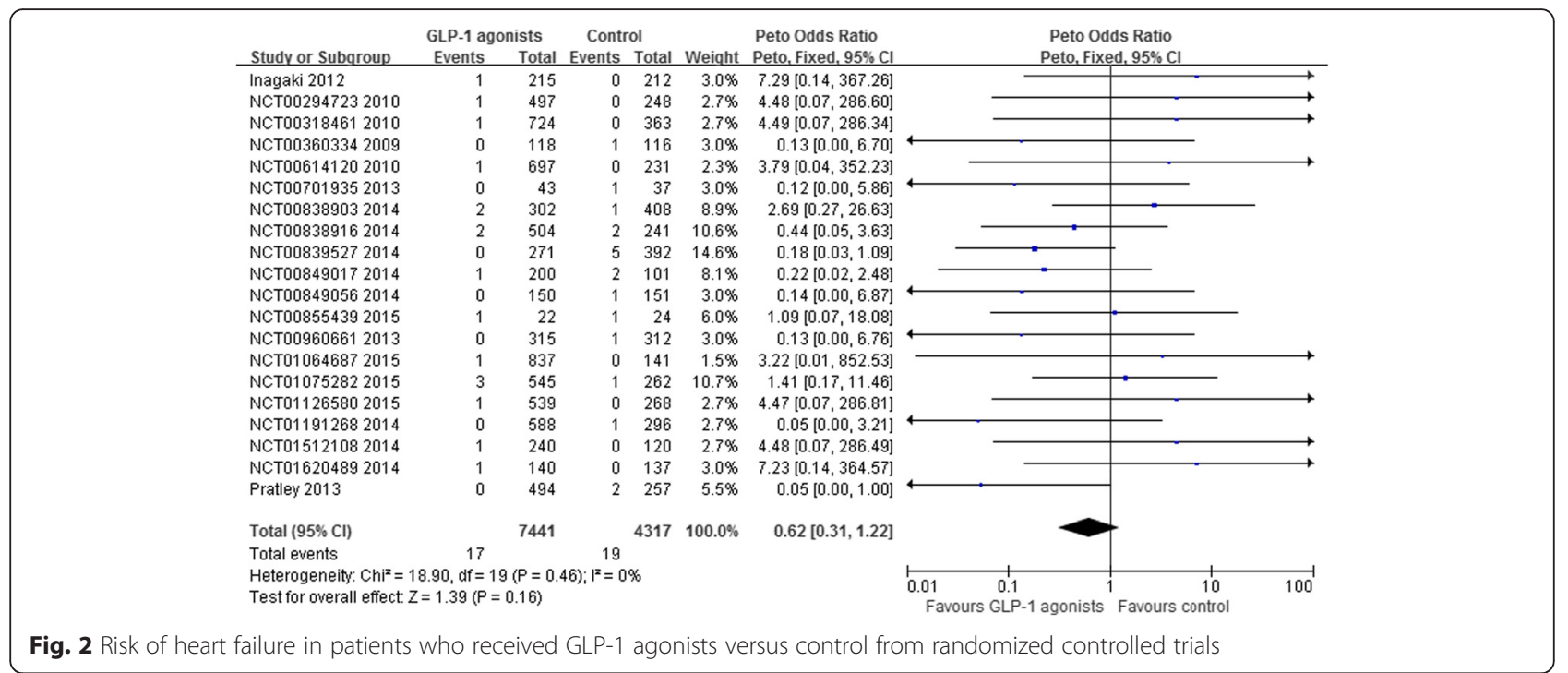

(Tables 4 and 5). This study included 57,737 patients, with a mean age of 61.6 years and mean duration of diabetes 2.3 years. The methodological details regarding the control for bias are provided in Additional file 8. This study included 1118 cases and 17,626 matched controls and found that, compared to the use of other antihyperglycemic drugs, GLP-1agonists were not associated with increased risk of hospitalization for congestive heart failure (adjusted OR 0.67, $95 \%$ CI 0.32 to 1.42). Using GRADE, we rated the quality of evidence as very low, due to risk of bias and imprecision in addition to the inherent risk for confounding associated with observational studies.

\section{Discussion}

\section{Main findings}

Our pooled analysis of 20 RCTs addressing use of GLP-1 agonists for type 2 diabetes found moderate quality evidence suggesting no increase in heart failure. The only RCT provided high quality evidence that lixisenatide did not increase the risk of hospitalization due to heart failure. Though the four observational studies provide only very low quality evidence, their results are consistent with those from the randomized trials.

\section{Strengths and limitations}

We are the first to systematically review the evidence regarding GLP-1 agonists for type 2 diabetes and risk of heart failure. Our study has several strengths. First, we used rigorous methods to systematically identify both randomized and observational studies that reported data to inform this issue, including a large number of trials that were not published in journals. Second, we carefully checked the data reported in ClinicalTrials.gov and journal publications for consistency to ensure accuracy of the data. Third, we analysed the data on heart failure and hospitalization for heart failure separately, because those outcomes are likely to be of different importance to patients. Fourth, we used the GRADE approach to assess the quality of evidence on an outcome-by-outcome basis.

Our study also has limitations. First, the available evidence is not strength to give definitive answer for this question, since the included RCTs reported few heart failure events and the follow-up was not enough for heart failure to occur, and much findings came from observational studies of very low quality evidence. Second, we have included some observational studies at moderate to high risk of bias. This has made the inference about the effects of GLP-1 agonists challenging. Third, the diversity of observational studies also made our analysis of the evidence difficult. One retrospective cohort study [18], assessing exenatide and/or insulin on heart failure outcome, included patients with heart failure at baseline, and the proportion of patients with history of heart failure was higher in the insulin group (3.2\%) than in the exenatide group (1.7\%) and exenatide + insulin group $(2.4 \%)$, which made the finding from this study biased.

\section{Other researches}

Ours is the first systematic review addressing the impact of GLP-1 agonists on heart failure. There is some evidence from human studies that GLP-1 agonists might provide protection against heart failure: preliminary study [67] showed that GLP-1 treatment might have a trend towards improvement of cardiac function in type 2 diabetes patients with stable heart failure; intrinsic GLP1 expression has been shown to compensatorily upregulate in patients with left heart failure [68]; and GLP-1 
Table 3 GRADE evidence profile of glucagon-like peptide-1 receptor agonists and risk of heart failure in type 2 diabetes

\begin{tabular}{|c|c|c|c|c|c|c|c|c|c|c|c|}
\hline \multicolumn{6}{|l|}{ Quality assessment } & \multicolumn{5}{|c|}{ Summary of findings } & \multirow{3}{*}{$\begin{array}{l}\text { Quality of } \\
\text { evidence }\end{array}$} \\
\hline \multirow[b]{2}{*}{$\begin{array}{l}\text { No of participants } \\
\text { (studies) } \\
\text { Follow-up time }\end{array}$} & \multirow[b]{2}{*}{ Risk of bias } & \multirow[b]{2}{*}{ Inconsistency } & \multirow[b]{2}{*}{ Indirectness } & \multirow[b]{2}{*}{ Imprecision } & \multirow[b]{2}{*}{$\begin{array}{l}\text { Publication } \\
\text { bias }\end{array}$} & \multicolumn{2}{|c|}{ Study event rates } & \multirow[t]{2}{*}{$\begin{array}{l}\text { Relative risk } \\
(95 \% \mathrm{Cl})\end{array}$} & \multicolumn{2}{|c|}{$\begin{array}{l}\text { Anticipated absolute } \\
\text { effects (5-year time frame) }\end{array}$} & \\
\hline & & & & & & With control & $\begin{array}{l}\text { With GLP-1 } \\
\text { agonists }\end{array}$ & & $\begin{array}{l}\text { Risk with } \\
\text { control }\end{array}$ & $\begin{array}{l}\text { Risk difference with } \\
\text { GLP-1 agonists } \\
(95 \% \text { Cl) }\end{array}$ & \\
\hline \multicolumn{12}{|l|}{ Heart failure } \\
\hline $\begin{array}{l}11758 \\
(20) \\
16-164 \text { weeks }\end{array}$ & $\begin{array}{l}\text { Serious } \\
\text { limitation due } \\
\text { to risk of } \\
\text { bias }^{a}\end{array}$ & $\begin{array}{l}\text { No serious } \\
\text { limitations }\end{array}$ & $\begin{array}{l}\text { No serious } \\
\text { limitations }\end{array}$ & $\begin{array}{l}\text { Serious limitation, } \\
\text { confidence interval } \\
\text { includes important } \\
\text { benefit and harm }\end{array}$ & Undetected & $\begin{array}{l}19 / 4317 \\
(0.44 \%)\end{array}$ & $\begin{array}{l}17 / 7441 \\
(0.23 \%)\end{array}$ & $\begin{array}{l}\text { OR } 0.62 \\
\text { (0.31 to } 1.22 \text { ) }\end{array}$ & $\begin{array}{l}50 \text { per } \\
1000^{b}\end{array}$ & $\begin{array}{l}19 \text { fewer per } 1000 \\
\text { (34 fewer to } 11 \text { more) }\end{array}$ & $\begin{array}{l}\oplus \oplus \bigcirc \bigcirc \\
\text { Low due to } \\
\text { risk of bias and } \\
\text { imprecision }\end{array}$ \\
\hline \multicolumn{12}{|c|}{ Hospitalization for heart failure } \\
\hline $\begin{array}{l}6068 \\
(1) \\
2.1 \text { years }\end{array}$ & $\begin{array}{l}\text { No serious } \\
\text { limitations }\end{array}$ & $\begin{array}{l}\text { No serious } \\
\text { limitations }\end{array}$ & $\begin{array}{l}\text { No serious } \\
\text { limitations }\end{array}$ & $\begin{array}{l}\text { Serious limitation, } \\
\text { confidence interval } \\
\text { includes important } \\
\text { benefit and harm }\end{array}$ & Undetected & $\begin{array}{l}127 / 3034 \\
4.2 \%\end{array}$ & $\begin{array}{l}122 / 3034 \\
4 \%\end{array}$ & $\begin{array}{l}\text { HR } 0.96 \\
\text { (0.75 to } 1.23 \text { ) }\end{array}$ & $\begin{array}{l}100 \text { per } \\
1000^{c}\end{array}$ & $\begin{array}{l}4 \text { fewer per } 1000 \\
\text { ( } 25 \text { fewer to } 23 \text { more) }\end{array}$ & $\begin{array}{l}\oplus \oplus \oplus O \\
\text { Moderate due } \\
\text { to imprecision }\end{array}$ \\
\hline
\end{tabular}

GLP-1 glucagon-like peptide-1

${ }^{a}$ Several trials probably had risk of bias on random sequence generation, allocation concealment and blinding (Additional file 2), and the follow up (median of 52 weeks) was not long enough for heart failure to occur in patients with low risk of cardiovascular disease

baseline risk estimate for heart failure in a 5-year time frame comes from the control arm of the cohort study we identified to best represent our target population (Kannan 2015 [17]), with 528 events of heart failure in 13,185 participants $(4.0 \%)$ at four year follow up across control and intervention arm

'Baseline risk estimate for hospitalization for heart failure in 5-year time frame comes from the control arm of the only included ELIXA trial [16] we identified to best represent our target population with 127 events in 3034 participants (42 per 1000) over a 2.1 year follow up period, in the absence of observational studies providing more credible baseline risk estimates 
Table 4 Characteristics of included observational studies

\begin{tabular}{|c|c|c|c|c|c|c|c|c|c|c|c|c|c|}
\hline Study & Study design & $\begin{array}{l}\text { Data } \\
\text { source }\end{array}$ & $\begin{array}{l}\text { Countries } \\
\text { involved }\end{array}$ & Funding & $\begin{array}{l}\text { Total } \\
\text { number } \\
\text { of } \\
\text { patients }\end{array}$ & $\begin{array}{l}\text { Follow } \\
\text { up } \\
\text { (years) }\end{array}$ & $\begin{array}{l}\text { Male } \\
(n, \%)\end{array}$ & $\begin{array}{l}\text { Mean } \\
\text { age } \\
\text { (years) }\end{array}$ & $\begin{array}{l}\text { Mean BMl } \\
\left(\mathrm{kg} / \mathrm{m}^{2}\right)\end{array}$ & $\begin{array}{l}\text { Mean } \\
\text { HbA1c (\%) }\end{array}$ & $\begin{array}{l}\text { Mean FPG } \\
(\mathrm{mmol} / \mathrm{L})\end{array}$ & $\begin{array}{l}\text { Mean diabetes } \\
\text { duration (years) }\end{array}$ & CVD at baseline \\
\hline \multicolumn{14}{|c|}{ Studies reporting heart failure } \\
\hline $\begin{array}{l}\text { NCT01060059 } \\
2013[66]\end{array}$ & $\begin{array}{l}\text { Prospective } \\
\text { cohort study }\end{array}$ & $\begin{array}{l}\text { Real } \\
\text { world } \\
\text { data }\end{array}$ & Italy & $\begin{array}{l}\text { Private } \\
\text { for-profit } \\
\text { funding }\end{array}$ & 882 & 1 & $\begin{array}{l}493 \\
(55.9)\end{array}$ & 62.5 & NR & 8.9 & NR & NR & NR \\
\hline Kannan $2015[17]^{a}$ & $\begin{array}{l}\text { Retrospective } \\
\text { cohort study }\end{array}$ & $\begin{array}{l}\text { Electronic } \\
\text { health } \\
\text { records }\end{array}$ & U.S. & $\begin{array}{l}\text { No } \\
\text { funding }\end{array}$ & 13,185 & $4^{b}$ & $\begin{array}{l}7827 \\
(54.6)\end{array}$ & 60.6 & $32.6^{c}$ & NR & NR & NR & $\begin{array}{l}\text { Included patients had } \\
\text { no history of CVD or } \\
\text { congestive heart failure } \\
\text { at baseline }\end{array}$ \\
\hline Paul 2015 [18] & $\begin{array}{l}\text { Retrospective } \\
\text { cohort study }\end{array}$ & $\begin{array}{l}\text { Claims } \\
\text { data }\end{array}$ & U.S. & NR & 39,225 & $3.5^{\mathrm{b}}$ & $\begin{array}{l}18093 \\
(46.1)\end{array}$ & 58.2 & 35.3 & 7.9 & NR & 1.3 & $\begin{array}{l}\text { Included patients had } \\
\text { CVD or no CVD at } \\
\text { baseline }\end{array}$ \\
\hline \multicolumn{14}{|c|}{ Studies reporting hospitalization for heart failure } \\
\hline Yu $2015[19]^{a}$ & $\begin{array}{l}\text { Nested case- } \\
\text { control study }\end{array}$ & $\begin{array}{l}\text { Electronic } \\
\text { medical } \\
\text { records }\end{array}$ & UK & $\begin{array}{l}\text { Public } \\
\text { funding }\end{array}$ & 57,737 & NA & $\begin{array}{l}32795 \\
(56.8)\end{array}$ & 61.6 & NR & NR & NR & 2.3 & $\begin{array}{l}\text { Included patients had } \\
\text { CVD or no CVD at } \\
\text { baseline }\end{array}$ \\
\hline
\end{tabular}

These two studies accessed incretin agents (both glucagon-like peptide-1 receptor agonists and dipeptidyl peptidase-4 inhibitors) and the risk of heart failure, so the data above were the characteristics of total patients included

$B M I$ body mass index, FPG fasting plasma glucose, CVD cardiovascular disease, NR not reported, NA not applicable

bmedian follow-up (years);

Median BMI (kg/m²) 
Table 5 Exposures, outcomes, and results of observational studies

\begin{tabular}{|c|c|c|c|c|c|c|}
\hline Study & $\begin{array}{l}\text { Exposure of } \\
\text { interest }\end{array}$ & Control group & $\begin{array}{l}\text { Number of } \\
\text { events or cases }\end{array}$ & $\begin{array}{l}\text { Total number } \\
\text { of analyzed } \\
\text { patients }\end{array}$ & $\begin{array}{l}\text { Adjusted estimates } \\
(95 \% \mathrm{Cl})\end{array}$ & Adjusted covariate \\
\hline
\end{tabular}

Studies reporting heart failure

$\begin{array}{lllll}\text { Kannan } 2015 & \text { GPL-1 agonists } & \text { Sulfonylureas } \\ \text { [17] } & \text { (combined with } & \text { (combined with } & & 13,185(55,110 \\ \text { metformine) } & \text { HR } 1.10 \text { (0.99 to 1.22) } & \text { person years) }\end{array}$

$\begin{array}{ll}\text { Paul } 2015 \quad \begin{array}{l}\text { Exenatide/ Insulin } \\ \text { exenatide } \\ \text { + insulin }\end{array} & \end{array}$

\author{
Exenatide vs insulin: \\ HR $0.34(0.22,0.52)$ \\ Exenatide + insulin vs insulin: \\ HR $0.40(0.32,0.50)$
}

\footnotetext{
NCT01060059 Exenatide Basal insulin 2013 [66]
}

Studies reporting hospitalization for heart failure

\begin{tabular}{|c|c|c|c|c|c|}
\hline Yu 2015 [19] & $\begin{array}{l}\text { GLP-1 agonists } \\
\text { (exenatide and } \\
\text { liraglutide, alone } \\
\text { or incombination } \\
\text { with other } \\
\text { antidiabetic drugs) }\end{array}$ & $\begin{array}{l}\text { Other oral } \\
\text { antidiabetic } \\
\text { drugs }\end{array}$ & $1,118^{a}$ & $18,744^{a}$ & OR 0.67 (0.32 to 1.42$)$ \\
\hline
\end{tabular}

Without previous CVD:

Exenatide vs insulin:

HR $0.34(0.22,0.52)$

Exenatide + insulin vs insulin:

HR $0.40(0.32,0.50)$

Without previous CVD

\& renal diseases:

Exenatide vs insulin:

$\operatorname{HR} 0.32(0.21,0.50)$

Exenatide + insulin vs insulin: HR $0.35(0.28,0.45)$

Age, sex, race, BMl, number of encounters, median household income, smoking status, systolic and diastolic blood pressure, hypertension, dyslipidemia, cerebral vascular event, presence of neuropathy, retinopathy, dementia, chronic obstructive pulmonary disease, cancer, atrial fibrillation, antihypertensive medications, lipid lowering agents, anti-platelet agents and propensity for being on metformin and sulfonylureas at baseline, lipid profile, estimated glomerular filtration rate

Gender, ethnicity, age at the start of cohort, BMl, HbA1c, systolic and diastolic blood pressure on the index date, history of cardiovascular disease, any renal disease prior to index date or during follow-up, use of metformin, sulfonylurea, cardioprotective medications or antihypertensive medications, and the duration of diabetes

NR

NR
Sex, BMI, excessive alcohol use, smoking status, HbA1c level, comorbidities (neuropathy, renal disease, retinopathy, atrial fibrillation, cancer [other than nonmelanoma skin cancer], chronic obstructive pulmonary disease, coronary artery disease, dyslipidemia, hypertension, previous myocardial infarction, peripheral arteriopathy, previous coronary revascularization, peripheral vascular disease, and previous stroke), number of prescriptions, number of physician visits, and use of the following drugs in the year prior to cohort entry: angiotensin converting enzyme inhibitors, angiotensin receptor blockers, $\beta$-blockers, calcium channel blockers, diuretics, fibrates, statins, aspirin, and other nonsteroidal anti-inflammatory drugs

${ }^{a}$ These two studies accessed incretin agents and the risk of heart failure, and the data of events/cases and total number of analyzed patients regarding glucagon-like peptide- 1 receptor agonists and dipeptidyl peptidase- 4 inhibitors were not reported separately, so the data above were the data of total study patients Cl confidence interval, NR not reported, HR hazard ratio, OR odds ratio, CVD cardiovascular disease, BMI body mass index 
Table 6 Risk of heart failure or hospitalization for heart failure among patients with type 2 diabetes receiving glucagon-like peptide-1 receptor agonists treatment

\begin{tabular}{|c|c|c|c|c|c|}
\hline Comparison & $\begin{array}{l}\text { Number of studies } \\
\text { (Events or cases, } \\
\text { patients) }\end{array}$ & $\begin{array}{l}\text { GLP-1 agonists } \\
\text { (events/patients) }\end{array}$ & $\begin{array}{l}\text { Control } \\
\text { (events/ } \\
\text { patients) }\end{array}$ & $\begin{array}{l}\text { Effect Estimate } \\
(95 \% \mathrm{Cl})\end{array}$ & $\begin{array}{l}\text { Cardiovascular morbidities } \\
\text { at baseline }\end{array}$ \\
\hline \multicolumn{6}{|l|}{ 1. Heart failure } \\
\hline \multicolumn{6}{|l|}{ Randomized controlled trials } \\
\hline GLP-1 agonists vs. control & $20(36,11758)$ & $17 / 7441$ & $19 / 4317$ & $\begin{array}{l}\text { Pooled OR } 0.62 \\
\text { (0.31 to } 1.22 \text { ) }\end{array}$ & $\begin{array}{l}\text { Typically without CVD } \\
\text { at baseline }\end{array}$ \\
\hline \multicolumn{6}{|l|}{ Cohort studies } \\
\hline GLP-1 agonists vs. SU & $1(528,13185)$ & NR & NR & $\begin{array}{l}\text { Adjusted HR } 1.10 \\
\text { (0.99 to } 1.22)\end{array}$ & $\begin{array}{l}\text { No history of CVD or } \\
\text { congestive heart failure } \\
\text { at baseline }\end{array}$ \\
\hline $\begin{array}{l}\text { Exenatide vs. insulin } \\
\text { Exenatide + insulin vs. insulin }\end{array}$ & $1(2338,39225)$ & $\begin{array}{l}49 / 2804 \\
195 / 7870\end{array}$ & $\begin{array}{l}2094 / 28551 \\
2094 / 28551\end{array}$ & $\begin{array}{l}\text { Adjusted HR } 0.34 \\
(0.22,0.52) \\
\text { Adjusted HR } 0.40 \\
(0.32,0.50)\end{array}$ & $\begin{array}{l}\text { With or without CVD } \\
\text { at baseline }\end{array}$ \\
\hline Exenatide vs. basal insulin & $1(2,882)$ & $0 / 444$ & $2 / 438$ & $\begin{array}{l}\text { Unadjusted OR } 0.13 \\
\text { (0.01 to } 2.13 \text { ) }\end{array}$ & $N R$ \\
\hline \multicolumn{6}{|l|}{ 2. Hospitalization for heart failure } \\
\hline \multicolumn{6}{|l|}{ Randomized controlled trials } \\
\hline Lixisenatide vs. placebo & $1(249,6068)$ & $122 / 3034$ & $127 / 3034$ & $\begin{array}{l}\text { Pooled Adjusted HR } \\
0.96(0.75,1.23)\end{array}$ & Acute coronary syndrome \\
\hline \multicolumn{6}{|l|}{ Nested case-control studies } \\
\hline GLP-1 agonists vs. other OADs & $1(1118,18744)$ & & & $\begin{array}{l}\text { Adjusted OR } 0.67 \\
(0.32 \text { to } 1.42)\end{array}$ & $\begin{array}{l}\text { With or without CVD } \\
\text { at baseline }\end{array}$ \\
\hline
\end{tabular}

GLP-1 glucagon-like peptide-1, CVD cardiovascular disease, SU sulfonylurea, OR odds ratio, HR hazard ratio, NR not reported, OADs oral antidiabetic drugs

agonists are also shown to be associated with a modest increase of ejection fraction in diabetic patients [69]. A recent meta-analysis of RCTs [70] found that GLP-1 agonists were associated with a modest reduction in blood pressure and a slight increase in heart rate. These biological studies suggest that GLP-1 agonists might, if anything, reduce the incidence of heart failure. Though results of RCTs fail to show this decrease, confidence intervals do not exclude the possibility of a modest reduction.

\section{Conclusions}

The current evidence suggests that GLP-1 agonists do not increase the risk of heart failure or hospitalization for heart failure. The current body of evidence, however, is not definitive. More carefully designed, conducted, adequately powered trials and observational studies are warranted to confirm the effects of GLP-1 agonists on incidence of heart failure and hospitalization for heart failure. Future studies should also examine whether the

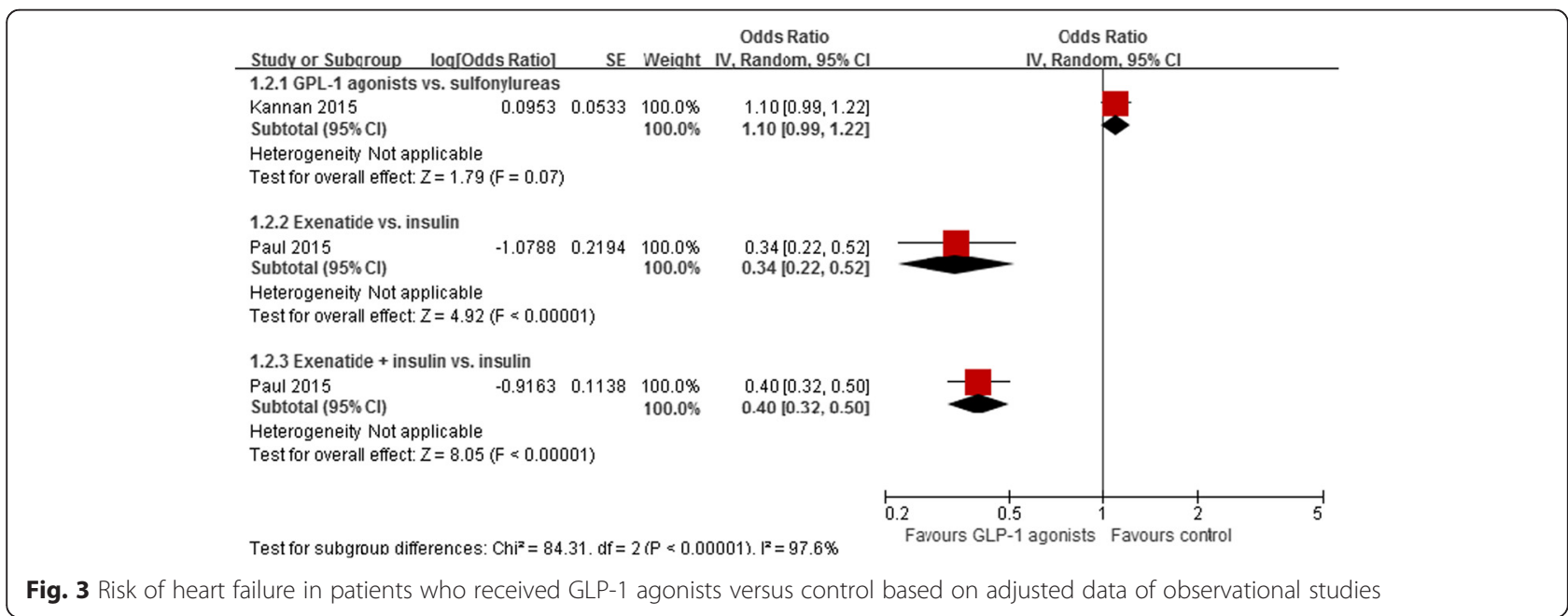


effects of GLP-1 agonists on heart failure are affected by patient's baseline risk of cardiovascular disease.

\section{Availability of data and materials}

The datasets supporting the conclusions of this article are included within the article and its additional files.

\section{Additional files}

Additional file 1: Search strategies. (DOC $35 \mathrm{~kb}$ )

Additional file 2: Risk of bias of included randomized controlled trials. (DOC $78 \mathrm{~kb}$ )

Additional file 3: Subgroup analysis of heart failure risk by type of control based on raw data of randomized controlled trials. (DOC $47 \mathrm{~kb}$ )

Additional file 4: Subgroup analysis of heart failure risk by mode of therapy based on raw data of randomized controlled trials. (DOC $45 \mathrm{~kb}$ )

Additional file 5: Subgroup analysis of heart failure risk by length of follow up based on raw data of randomized controlled trials. (DOC $45 \mathrm{~kb}$ )

Additional file 6: Subgroup analysis of heart failure risk by individual GLP-1 agonists agents based on raw data of randomized controlled trials. (DOC $55 \mathrm{~kb}$ )

Additional file 7: Risk of bias of included cohort studies. (DOC 55 kb) Additional file 8: Risk of bias of included case-control studies. (DOC $52 \mathrm{~kb}$ )

\section{Abbreviations}

BMI: body mass index; CENTRAL: the Cochrane Central Register of Controlled Trials; Cl: confidence interval; DPP-4: dipeptidyl peptidase-4; ELIXA: Evaluation of LIXisenatide in Acute Coronary Syndrome; FPG: fasting plasma glucose; GLP1: glucagon-like peptide-1; GRADE: Grading of Recommendations Assessment, Development and Evaluation; HbA1c: glycated haemoglobin; HR: hazard ratio; MOOSE: Meta-analysis Of Observational Studies in Epidemiology; OR: odds ratio; PRISMA: Preferred Reporting Items for Systematic Reviews and Meta-Analyses; $\mathrm{RCT}$ s: randomized controlled trials; RD: risk difference.

\section{Competing interests}

This study was supported by National Natural Science Foundation of China (Grant No. 71573183), "Thousand Youth Talents Plan" of China (Grant No: D1024002) and Sichuan Province, and Young Investigator Award, Sichuan University (Grant No: 2013SCU04A37). These funders had no role in the study design, writing of the manuscript, or decision to submit this or future manuscripts for publication. SL is funded by the National Natural Science Foundation of China (Grant No. 81400811 and 21534008). JWB is funded by a New Investigator Award from the Canadian Institutes of Health Research and Canadian Chiropractic Research Foundation. ZNS is funded by the Canadian Diabetes Association. SE is funded by MITACS Elevate and Restracomp Postdoctoral Awards.

\section{Authors' contributors}

XS and SL conceived the study. XS acquired the funding. XS and LL had full access to all of the data in the study, and take responsibility for the integrity of the data and the accuracy of the data analysis. XS and LL designed the study. XS and $L L$ developed and tested the data collection forms. $L L, J L, K D$ JWB, POV, EW, ZNS, MMB, LPR, GM, SE, JS, LZ, PZ, QC and YW acquired the data. $L L$ and $X S$ conducted the analysis and interpreted the data. $L L$ and $X S$ drafted the manuscript. LL, XS, SL, JWB, POV, GHG, JL, KD, EW, ZNS, MMB, $L P R, G M, S E, J S, L Z, P Z, Q C$ and YW critically revised the manuscript. XS is the guarantor. All authors read and approved the final manuscript.

\section{Acknowledgements}

The authors would like to thank Daphne Plaut for developing the search strategy and conducting the initial literature search.

\section{Author details}

${ }^{1}$ Chinese Evidence-based Medicine Center, West China Hospital, Sichuan University, 37 GuoXue Xiang, Chengdu 610041, Sichuan, China. ²Department of Endocrinology and Metabolism, West China Hospital, Sichuan University, Chengdu, Sichuan, China. ${ }^{3}$ West China school of Pharmacy, Sichuan University, Chengdu, Sichuan, China. ${ }^{4}$ Department of Clinical Epidemiology and Biostatistics, McMaster University, Hamilton, ON, Canada. ${ }^{5}$ Department of Anesthesia, McMaster University, Hamilton, ON, Canada. ${ }^{6}$ The Michael G. DeGroote Institute for Pain Research and Care, McMaster University, Hamilton, ON, Canada. ${ }^{7}$ Norwegian Knowledge Centre for the Health Services, Oslo, Norway. ${ }^{8}$ Department of Medicine, Innlandet Hospital Trust, Gjøvik, Norway. ${ }^{9}$ Department of Medicine, University of British Columbia, Vancouver, BC, Canada. ${ }^{10}$ Faculty of Medicine, University of Toronto, 1 King's College Circle, Toronto, ON, Canada. ${ }^{11}$ Department of Hygiene and Dietetics, Jagiellonian University Medical College, Krakow, Poland. ${ }^{12}$ Systematic Reviews Unit-Polish Cochrane Branch, Jagiellonian University Medical College, Krakow, Poland. ${ }^{13}$ Internal Medicine Unit, Hospital Clinico FUSAT, Rancagua, Chile. ${ }^{14}$ Department of Medicine, Universidad Peruana Cayetano Heredia, Lima, Peru. ${ }^{15}$ Stanford Prevention Research Center, Department of Medicine, Stanford University, Stanford, USA. ${ }^{16}$ Department of Anaesthesia \& Pain Medicine, The Hospital for Sick Children, Toronto, ON, Canada. ${ }^{17}$ The Second Hospital of Lanzhou University, Lanzhou, China. ${ }^{18}$ Department of Medical Administration, 363 Hospital, Chengdu, Sichuan, China. ${ }^{19}$ Department of Medicine, McMaster University, Hamilton, ON, Canada.

Received: 9 February 2016 Accepted: 29 April 2016

Published online: 11 May 2016

\section{References}

1. Aroda VR, Henry RR, Han J, Huang W, DeYoung MB, Darsow T, et al. Efficacy of GLP-1 receptor agonists and DPP-4 inhibitors: meta-analysis and systematic review. Clin Ther. 2012;34(6):1247-58.e22.

2. Liu FP, Dong JJ, Yang Q, Xue XZ, Ren ZF, Gan YZ, et al. Glucagon-like peptide 1 receptor agonist therapy is more efficacious than insulin glargine for poorly controlled type 2 diabetes: A systematic review and metaanalysis. J Diabetes. 2015;7(3):322-8.

3. Vilsboll T, Christensen M, Junker AE, Knop FK, Gluud LL. Effects of glucagonlike peptide-1 receptor agonists on weight loss: systematic review and meta-analyses of randomised controlled trials. BMJ. 2012;344:d7771.

4. Wu S, Sun F, Zhang Y, Yang Z, Hong T, Chen Y, et al. The cardiovascular effects of glucagon-like peptide-1 receptor agonists: a trial sequential analysis of randomized controlled trials. J Clin Pharm Ther. 2014;39(1):7-13.

5. Monami M, Dicembrini I, Nardini C, Fiordelli I, Mannucci E. Effects of glucagon-like peptide-1 receptor agonists on cardiovascular risk: a metaanalysis of randomized clinical trials. Diabetes Obes Metab. 2014;16(1):38-47.

6. Inzucchi SE, Bergenstal RM, Buse JB, Diamant M, Ferrannini E, Nauck M, et al. Management of hyperglycemia in type 2 diabetes, 2015: a patient-centered approach: update to a position statement of the American Diabetes Association and the European Association for the Study of Diabetes. Diabetes Care. 2015;38(1):140-9.

7. U.S. Food and Drug Administration. Saxagliptin (marketed as Onglyza and Kombiglyze XR): Drug Safety Communication - FDA to Review Heart Failure Risk. http://www.fda.gov/Safety/MedWatch/ SafetyInformation/SafetyAlertsforHumanMedicalProducts/ucm 385471. htm. Accessed 27 Aug 2015.

8. Scirica BM, Bhatt DL, Braunwald E, Steg PG, Davidson J, Hirshberg B, et al. Saxagliptin and cardiovascular outcomes in patients with type 2 diabetes mellitus. N Engl J Med. 2013;369(14):1317-26.

9. Wang KL, Liu CJ, Chao TF, Huang CM, Wu CH, Chen SJ, et al. Sitagliptin and the risk of hospitalization for heart failure: a population-based study. Int J Cardiol. 2014;177(1):86-90.

10. Weir DL, McAlister FA, Senthilselvan A, Minhas-Sandhu JK, Eurich DT. Sitagliptin use in patients with diabetes and heart failure: a populationbased retrospective cohort study. JACC Heart Fail. 2014;2(6):573-82.

11. Noyan-Ashraf MH, Momen MA, Ban K, Sadi AM, Zhou YQ, Riazi AM, et al. GLP-1R agonist liraglutide activates cytoprotective pathways and improves outcomes after experimental myocardial infarction in mice. Diabetes. 2009; 58(4):975-83.

12. Chilton R, Wyatt J, Nandish S, Oliveros R, Lujan M. Cardiovascular comorbidities of type 2 diabetes mellitus: defining the potential of glucagonlike peptide-1based therapies. Am J Med. 2011;124(1 Suppl):S35-53.

13. Drucker DJ, Goldfine AB. Cardiovascular safety and diabetes drug development. Lancet. 2011;377(9770):977-9. 
14. Nikolaidis LA, Mankad S, Sokos GG, Miske G, Shah A, Elahi D, et al. Effects of glucagon-like peptide-1 in patients with acute myocardial infarction and left ventricular dysfunction after successful reperfusion. Circulation. 2004;109(8):962-5.

15. Bentley-Lewis R, Aguilar D, Riddle MC, Claggett B, Diaz R, Dickstein K, et al. Rationale, design, and baseline characteristics in Evaluation of LIXisenatide in Acute Coronary Syndrome, a long-term cardiovascular end point trial of lixisenatide versus placebo. Am Heart J. 2015;169(5):631-8.e7.

16. Lewis EF, Evaluation of LIXisenatide in Acute Coronary Syndrome (ELIXA). European Society of Cardiology Congress 2015: Hot Line III - Diabetes mellitus/Pharmacology. Presented on August 31, 2015. http://congress365. escardio.org/Search-Results?vgnextkeyword=ELIXA\#.VjsFJfnMVLA.

17. Kannan S, Pantalone KM, Matsuda S, Wells BJ, Karafa M, Zimmerman RS. Risk of overall mortality and cardiovascular events in patients with type 2 diabetes on dual drug therapy including metformin: A large database study from the Cleveland Clinic. J Diabetes. 2015. doi:10.1111/753-0407.12301 [Epub ahead of print].

18. Paul SK, Klein K, Maggs D, Best JH. The association of the treatment with glucagon-like peptide-1 receptor agonist exenatide or insulin with cardiovascular outcomes in patients with type 2 diabetes: a retrospective observational study. Cardiovasc Diabetol. 2015;14:10.

19. Yu OH, Filion KB, Azoulay L, Patenaude V, Majdan A, Suissa S. Incretin-based drugs and the risk of congestive heart failure. Diabetes Care. 2015;38(2):277-84

20. Moher D, Liberati A, Tetzlaff J, Altman DG. Preferred reporting items for systematic reviews and meta-analyses: the PRISMA statement. BMJ. 2009; 339:b2535.

21. Stroup DF, Berlin JA, Morton SC, Olkin I, Williamson GD, Rennie D, et al. Meta-analysis of observational studies in epidemiology: a proposal for reporting. Meta-analysis Of Observational Studies in Epidemiology (MOOSE) group. JAMA. 2000;283(15):2008-12.

22. Higgins JPT AD, Sterne JAC. Assessing risk of bias in included studies. In Higgins JPT, Green S, eds. Cochrane handbook for systematic reviews of interventions. Version 5.1.0. Cochrane Collaboration, 2011.

23. Guyatt GH, Busse JW. Modification of Cochrane Tool to assess risk of bias in randomized trials. http://distillercer.com/resources/. Accessed 06 Dec 2015

24. Akl EA, Sun X, Busse JW, Johnston BC, Briel M, Mulla S, et al. Specific instructions for estimating unclearly reported blinding status in randomized trials were reliable and valid. J Clin Epidemiol. 2012;65(3):262-7.

25. Wells GA SB, O'Connell D, Peterson J, Welch V, Losos M, et al. The Newcastle-Ottawa Scale (NOS) for Assessing the Quality of Non-Randomized Studies in Meta-Analysis. http://www.ohri.ca/programs/clinical_ epidemiology/oxford.asp. Accessed 25 Aug 2015

26. Busse JW, Guyatt GH. Tool to Assess Risk of Bias in Cohort Studies. http:// distillercer.com/resources/. Accessed 06 Dec 2015

27. Busse JW, Guyatt GH. Tool to Assess Risk of Bias in Case-control Studies. http://distillercer.com/resources/. Accessed 06 Dec 2015

28. Guyatt GH, Oxman AD, Vist GE, Kunz R, Falck-Ytter Y, Alonso-Coello P, et al, GRADE: an emerging consensus on rating quality of evidence and strength of recommendations. BMJ. 2008;336(7650):924-6.

29. Guyatt GH, Oxman AD, Vist G, Kunz R, Brozek J, Alonso-Coello P, et al. GRADE guidelines: 4. Rating the quality of evidence-study limitations (risk of bias). J Clin Epidemiol. 2011:64(4):407-15.

30. Guyatt GH, Oxman AD, Kunz R, Brozek J, Alonso-Coello P, Rind D, et al. GRADE guidelines 6 . Rating the quality of evidence-imprecision. J Clin Epidemiol. 2011;64(12):1283-93.

31. Guyatt $\mathrm{GH}$, Oxman AD, Kunz R, Woodcock J, Brozek J, Helfand M, et al GRADE guidelines: 7. Rating the quality of evidence-inconsistency. J Clin Epidemiol. 2011;64(12):1294-302

32. Guyatt GH, Oxman AD, Kunz R, Woodcock J, Brozek J, Helfand M, et al. GRADE guidelines: 8. Rating the quality of evidence-indirectness. J Clin Epidemiol. 2011;64(12):1303-10.

33. Guyatt GH, Oxman AD, Montori V, Vist G, Kunz R, Brozek J, et al. GRADE guidelines: 5. Rating the quality of evidence-publication bias. J Clin Epidemiol. 2011;64(12):1277-82

34. Guyatt GH, Oxman AD, Sultan S, Glasziou P, Akl EA, Alonso-Coello P, et al. GRADE guidelines: 9. Rating up the quality of evidence. J Clin Epidemiol. 2011;64(12):1311-6.

35. Higgins JPT DJSsacdIHJ, Green S, eds. Cochrane handbook for systematic reviews of interventions. Version 5.1.0. Cochrane Collaboration, 2011.

36. Bradburn MJ, Deeks JJ, Berlin JA, Russell LA. Much ado about nothing: a comparison of the performance of meta-analytical methods with rare events. Stat Med. 2007;26(1):53-77.
37. Higgins JPT DJ, Altman DG. Special topics in statistics. In Higgins JPT, Green S, (eds) Cochrane handbook for systematic reviews of interventions. Version 5.1.0. Cochrane Collaboration, 2011.

38. Inagaki N, Atsumi Y, Oura T, Saito H, Imaoka T. Efficacy and Safety Profile of Exenatide Once Weekly Compared With Insulin Once Daily in Japanese Patients With Type 2 Diabetes Treated With Oral Antidiabetes Drug(s): Results From a 26-Week, Randomized, Open-Label, Parallel-Group, Multicenter, Noninferiority Study. Clin Ther. 2012;34(9):1892-908.e1.

39. AstraZeneca, Eli Lilly and Company. Study to evaluate the efficacy and safety of exenatide once-weekly injection compared to once-daily insulin in type 2 diabetes mellitus. National Library of Medicine (US), 2000. http:// clinicaltrials.gov/show/NCT00935532.

40. Novo Nordisk A/S. To evaluate the effect of liraglutide versus glimepiride $\left(\right.$ Amaryl ${ }^{\oplus}$ ) on haemoglobin A1c (LEAD-3). National Library of Medicine (US), 2000. http://clinicaltrials.gov/show/NCT00294723.

41. Garber A, Henry R, Ratner R, Garcia-Hernandez PA, Rodriguez-Pattzi H, Olvera-Alvarez I, et al. Liraglutide versus glimepiride monotherapy for type 2 diabetes (LEAD-3 Mono): a randomised, 52-week, phase III, double-blind, parallel-treatment trial. Lancet. 2009:373(9662):473-81.

42. Novo Nordisk. To compare the effect of liraglutide when given together with metformin with the effect of metformin given alone and with the effect of glimepiride and metformin given together (LEAD-2). National Library of Medicine (US), 2000. http://clinicaltrials.gov/show/NCT00318461.

43. Nauck M, Frid A, Hermansen K, Thomsen AB, During M, Shah N, et al. Longterm efficacy and safety comparison of liraglutide, glimepiride and placebo, all in combination with metformin in type 2 diabetes: 2-year results from the LEAD-2 study. Diabetes Obes Metab. 2013;15(3):204-12.

44. Nauck M, Frid A, Hermansen K, Shah NS, Tankova T, Mitha IH, et al. Efficacy and safety comparison of liraglutide, glimepiride, and placebo, all in combination with metformin, in type 2 diabetes: the LEAD (liraglutide effect and action in diabetes)-2 study. Diabetes Care. 2009;32(1):84-90.

45. AstraZeneca, Eli Lilly and Company. A study comparing exenatide with basal insulin in achieving a target $\mathrm{HbA1c}$ with minimum weight gain in type 2 diabetes patients. National Library of Medicine (US), 2000. http://clinicaltrials.gov/show/NCT00360334.

46. Novo Nordisk A/S. Effect of liraglutide or glimepiride added to metformin on blood glucose control in subjects with type 2 diabetes. National Library of Medicine (US), 2000. http://clinicaltrials.gov/show/NCT00614120.

47. AstraZeneca, Eli Lilly and Company. Effect of exenatide on abdominal fat distribution in patients with type 2 diabetes pretreated with metformin. National Library of Medicine (US), 2000. http://clinicaltrials.gov/show/ NCT00701935.

48. GlaxoSmithKline. Efficacy and safety of albiglutide in treatment of type 2 diabetes. National Library of Medicine (US), 2000. http://clinicaltrials.gov/ show/NCT00838903.

49. Ahren B, Johnson SL, Stewart M, Cirkel DT, Yang F, Perry C, et al. HARMONY 3: 104-week randomized, double-blind, placebo- and active-controlled trial assessing the efficacy and safety of albiglutide compared with placebo, sitagliptin, and glimepiride in patients with type 2 diabetes taking metformin. Diabetes Care. 2014;37(8):2141-8.

50. GlaxoSmithKline. A study to determine the safety and efficacy of albiglutide in patients with type 2 diabetes. National Library of Medicine (US), 2000. http://clinicaltrials.gov/show/NCT00838916.

51. Weissman PN, Carr MC, Ye J, Cirkel DT, Stewart M, Perry C, et al. HARMONY 4: randomised clinical trial comparing once-weekly albiglutide and insulin glargine in patients with type 2 diabetes inadequately controlled with metformin with or without sulfonylurea. Diabetologia. 2014;57(12):2475-84.

52. GlaxoSmithKline. A study to determine the safety and efficacy of albiglutide in subjects with type 2 diabetes. National Library of Medicine (US), 2000 http://clinicaltrials.gov/show/NCT00839527.

53. GlaxoSmithKline. Safety and efficacy study of albiglutide in type 2 diabetes. National Library of Medicine (US), 2000. http://clinicaltrials.gov/show/ NCT00849017.

54. GlaxoSmithKline. Safety and efficacy of albiglutide in type 2 diabetes. National Library of Medicine (US), 2000. http://clinicaltrials.gov/show/ NCT00849056.

55. University of Michigan, Amylin Pharmaceuticals, LLC, Eli Lilly and Company. Evaluation of exenatide in patients with diabetic neuropathy. National Library of Medicine (US), 2000. http://clinicaltrials.gov/show/NCT00855439.

56. AstraZeneca; Eli Lilly and Company. A trial comparing two therapies: basal insulin/glargine, exenatide and metformin therapy (BET) or basal insulin/ 
glargine, bolus insulin lispro and metformin therapy (BBT) in subjects with type 2 diabetes. National Library of Medicine (US), 2000. http://clinicaltrials. gov/show/NCT00960661.

57. Diamant M, Nauck MA, Shaginian R, Malone JK, Cleall S, Reaney M, et al. Glucagon-like peptide 1 receptor agonist or bolus insulin with optimized basal insulin in type 2 diabetes. Diabetes Care. 2014;37(10):2763-73.

58. Eli Lilly and Company. A Study in participants with type 2 diabetes mellitus (AWARD-1). National Library of Medicine (US), 2000. http://clinicaltrials.gov/ show/NCT01064687.

59. Eli Lilly and Company. A study in participants with type 2 diabetes mellitus (AWARD-2). National Library of Medicine (US), 2000. http://clinicaltrials.gov/ show/NCT01075282.

60. Eli Lilly and Company. A Study in participants with type 2 diabetes mellitus (AWARD-3). National Library of Medicine (US), 2000. http://clinicaltrials.gov/ show/NCT01126580

61. Umpierrez G, Tofe Povedano S, Perez Manghi F, Shurzinske L, Pechtner V. Efficacy and safety of dulaglutide monotherapy versus metformin in type 2 diabetes in a randomized controlled trial (AWARD-3). Diabetes Care. 2014; 37(8):2168-76.

62. Eli Lilly and Company. A study in participants with type 2 diabetes mellitus (AWARD-4). National Library of Medicine (US), 2000. http://clinicaltrials.gov/ show/NCT01191268.

63. Novo Nordisk A/S. Safety and efficacy of liraglutide in combination with an oad in subjects with type 2 diabetes insufficiently controlled on oad alone. National Library of Medicine (US), 2000. http://clinicaltrials.gov/show/ NCT01512108.

64. Novo Nordisk A/S. Efficacy and safety of liraglutide versus placebo as addon to existing diabetes medication in subjects with type 2 diabetes and moderate renal impairment. National Library of Medicine (US), 2000. http://clinicaltrials.gov/show/NCT01620489.

65. Pratley RE, Urosevic D, Boldrin M, Balena R. Efficacy and tolerability of taspoglutide versus pioglitazone in subjects with type 2 diabetes uncontrolled with sulphonylurea or sulphonylurea-metformin therapy: A randomized, double-blind study (T-emerge 6). Diabetes Obes Metab. 2013; 15(3):234-40.

66. AstraZeneca, Eli Lilly and Company. Exenatide and Basal Insulins Use in the Real Setting: an Observational Study in Patients With Type 2 Diabetes. In: ClinicalTrials.gov [Internet]. National Library of Medicine (US), 2000 http://clinicaltrials.gov/show/NCT01060059.

67. Thrainsdottir I, Malmberg K, Olsson A, Gutniak M, Ryden L. Initial experience with GLP-1 treatment on metabolic control and myocardial function in patients with type 2 diabetes mellitus and heart failure. Diab Vasc Dis Res. 2004;1(1):40-3.

68. Hattori A, Kawamura I, Yamada Y, Kanamori H, Aoyama T, Ushikoshi H, et al. Elevated plasma GLP-1 levels and enhanced expression of cardiac GLP-1 receptors as markers of left ventricular systolic dysfunction: a cross-sectional study. BMJ Open. 2013;3(9), e003201.

69. Liu R, Li L, Chen Y, Yang M, Liu H, Yang G. Effects of glucagon-like peptide-1 agents on left ventricular function: systematic review and meta-analysis. Ann Med. 2014:46(8):664-71.

70. Sun F, Wu S, Guo S, Yu K, Yang Z, Li L, et al. Impact of GLP-1 receptor agonists on blood pressure, heart rate and hypertension among patients with type 2 diabetes: A systematic review and network meta-analysis. Diabetes Res Clin Pract. 2015;110(1):26-37.

\section{Submit your next manuscript to BioMed Central and we will help you at every step:}

- We accept pre-submission inquiries

- Our selector tool helps you to find the most relevant journal

- We provide round the clock customer support

- Convenient online submission

- Thorough peer review

- Inclusion in PubMed and all major indexing services

- Maximum visibility for your research

Submit your manuscript at www.biomedcentral.com/submit

) Biomed Central 